\title{
Analysis of Sports and Social Skill Relation in a Non-Sportive Group
}

\author{
Aylin Zekioglu ${ }^{1}$, Arkun Tatar ${ }^{2}$, Hudanur Ozdemir ${ }^{3}$ \\ ${ }^{1}$ Manisa Celal Bayar University, Sports Science Faculty, Manisa, Turkey \\ ${ }^{2}$ FSM Waqf University, Faculty of Literature, Department of Psychology, Istanbul, Turkey \\ ${ }^{3}$ Psychologist-Istanbul, Turkey \\ Correspondence: Aylin Zekioglu, Manisa Celal Bayar University, Sports Science Faculty, Manisa, Turkey.
}

Received: April 25, 2018

Accepted: May 31, $2018 \quad$ Online Published: June 19, 2018

doi:10.11114/jets.v6i8.3233

URL: https://doi.org/10.11114/jets.v6i8.3233

\begin{abstract}
The aim of this study is to examine the relationship between social skills and sports participation of non-athlete participants. The data of this study were collected by using the Convenience Sampling Method from 197 females (59.3\%) and 135 males (40.7\%), a total of 332 participants, ranging in age from 17 to 67 years (mean=28.72 \pm 9.31 years). When asked about the frequency of engaging in sports, while $43(13.0 \%)$ of the respondents reported regular participation and $117(53.3 \%)$ reported occasional participation, and 112 (33.7\%) were non-participants. The participants completed the "A Social Skills Scale" for adults consisting of 80 items, and the Socio-demographic Form. The results showed that the Internal Consistency Coefficient for the scale was 0.93. In order to compare the three groups (regular participants, occasional participants, and non-participants) and other variables in terms of the total score of the scale, the two-way ANOVA test was used. There were significant differences in social skill degrees between three groups which were constituted based on frequency of sports participation, between the genders, and between the two groups that were formed considering where participants spent most of their lives (big cities or small towns). On the other hand, no significant difference was observed between participants' social skills according to age and socioeconomic variables like marital status, education, occupational and financial status. Findings were discussed in the context of the related literature.
\end{abstract}

Keywords: sports participation, social skills, non-athletes, social interactions

\section{Introduction}

Aside from motivating a healthy and fit lifestyle, socialization goals are also considered to be one of the factors that encourage individuals to engage in sport (Oliveira-Brochado, Brito \& Oliveira-Brochado, 2017; Trost, Owen, Bauman, Sallis \& Brown, 2002). Sports clubs, fitness centers, and the areas/halls allocated for sportive activities in residential areas pave the way for social interaction, and individuals using such areas have more active participation in social life (Kenyon \& McPherson, 1974; Vilhjalmsson \& Thorlindsson, 1992). In this respect, it is considered that sports and social skills are closely related. Particularly the sports that involve sharing the same environment with other people or that involve teamwork require social skills such as internalizing social norms, organizing behaviors according to rules, respecting others, initiating and sustaining publicity, communicating with others, cooperating with the group, taking responsibility and providing appropriate feedback (Gould, Flett, \& Lauer, 2012; Kay, 2009; Sage, 1979). These skills improve interpersonal communication and are effective in sustaining participation in sporting activities (Bailey, 2005; Ferguson, \& Shapiro, 2016; Light, 2010). Social skills, on the other hand, are the verbal or non-verbal behavioral communication skills of an individual in line with the social norms to sustain his/her life in agreement with the social circle. Social skills enable the individual to establish proper communications with other people and contribute to having a positive impact on them. In addition, they also consist of skills such as perceiving the clues coming from the social circle, interpreting these clues according to different situations, showing proper behaviors that fit these situations, and increase the efficiency of the individual in social relations (Tatar et al., 2018).

It has been shown through various studies that sport has an effect on acquiring and developing social skills (Gould \& Carson, 2008; Holt \& Neely, 2011; McNeill, Kreuter \& Subramanian, 2006). It has been suggested that regular sports participation during childhood and adolescence contributes to the social skill acquisition such as cooperation, seeking rights, awareness of responsibilities, establishing empathy, self-control, and leadership; as a consequence, the 
aggressiveness level is decreased and positive peer relations are maintained in this respect (Fraser-Thomas, Côté \& Deakin, 2005; Perron-Gélinas, Brendgen \& Vitaro, 2017; Shachar, Ronen-Rosenbaum, Rosenbaum, Orkibi \& Hamama, 2016). In addition to these, it is considered that socializing through sports activities in old age period contributes to social skills such as empathy and control of impulses; and affects the self-sufficiency levels of individuals in a positive manner (Lee, Kim \& Yi, 2014). Nevertheless, it is observed that the relationship between sporting and social isolation is negatively related to the social life in the aging period, and individuals dealing with sports show more participation in social life (Gayman, Fraser-Thomas, Dionigi, Horton \& Baker, 2017; Toepoel, 2013).

Empirical studies carried out to examine social skills through sportive activities also support the findings that those who have the opportunity to participate in a community or to establish individual relationships through social skills training programs in sportive contexts have been able to generalize their skills to the other areas of their social lives and have adopted a more positive attitude in their interpersonal relationships. In addition, there has been an increase in self-efficacy and self-esteem levels of individuals depending on the sport and the feedback they received from the people around (Ferguson \& Shapiro, 2016; Fraser-Thomas, et al., 2005; Hupp \& Reitman, 1999; Smith, 2003).

As well as the increase in self-confidence levels of individuals, regular sports participation enables people to become more active and more successful in their social environments such as school and workplace (Boekel et al., 2016; Muñoz- Bullón, Sanchez-Bueno \& Vos-Saz, 2017). However, there are differences between sports-doers and those who do not in terms of controlling emotion, depression, anxiety, aggression levels and school/job abandonment. It has been reported that those who participate in sports are less likely to face with such negative situations than those who do not participate in sports (Eime, Young, Harvey, Charity \& Payne, 2013; Jones \& Lavallee, 2009; Perron-Gélinas et al., 2017; Vilhjalmsson \& Thorlindsson, 1992).

The frequency of doing sports and participation of adult individuals in sportive activities is influenced at a certain ratio by environmental factors such as the place to live, the politics targeting social inclusion (Bailey, 2005; Downward \& Riordan, 2007; Liu, 2009; McNeill et al., 2006) and by demographic characteristics such as gender, age, marital status, and socio-economic level (Allender, Cowburn \& Foster, 2006; Hatfield, Chomitz, Chui, Sacheck \& Economos, 2015; Oliveira-Brochado et al., 2017; Trost et al., 2002). In this study, it is aimed to examine comparatively whether there is a difference in social skill levels in terms of socio-demographic groups depending on whether individuals participate in sports or not. It has been assumed that engaging in sporting activities will provide a skill-level increase in social relations with individuals, and that individuals will be more sociable. In this respect, it is planned to compare the social skill levels in this study provided that other socio-demographic characteristics of the individuals who do and who do not regularly participate in sports are taken into consideration.

\section{Methods}

\subsection{Participants}

A total of 332 people who were selected according to the Convenience Sampling Method between the ages 17 and 67 (mean $=28.72 \pm 9.31$ years) participated in the study. 197 participants were female $(59.3 \%)$, and 135 were male $(40.7 \%)$. Forty-three (13.0\%) of the participants stated that they did regular sports, $177(53.3 \%)$ stated that they did sports from time to time, and 112 (33.7\%) stated that they never did sports.

\subsection{Instrument}

In the present study, the participants answered the questionnaire that consisted of several questions and "A Social Skills Scale" for adults, which consisted of 80 questions 24 of which were responded in reverse order. The scale, which is in the form of "self-report", was designed in 5-point likert style (Never=1; Always=5). High points in the scale show that individuals has high social skill levels. The scale was developed through two studies one of which was conducted with 1210 participants between the ages of 18 and 69, and the other with 2186 participants between the ages of 18 and 72 . The Cronbach's Alpha internal consistency coefficient for the scale was determined to be 0.96 in both applications. The sample items of the scale were; "I think about it when necessary." (+) "I participate in the conversation in a comfortable manner in a crowded group." (+) "I have difficulty in apologizing." (-) (Tatar et al., 2018).

\subsection{Procedure}

The individuals were asked if they wanted to participate in the study voluntarily; and the volunteering individuals, from whom participation approvals were received, were given the scale and the questionnaire paper form to answer. Individuals who wanted to abandon the study were allowed without asking for excuses. The application for one individual lasted 15-20 minutes.

\subsection{Statistical Analysis}

In the evaluation of the data, the following procedures, i.e. determining the number and percentage distributions of the 
independent socio-demographic variables, examining the internal consistency of the scale, examining the sub-groups with two-way analysis of variance were carried out in terms of the overall score of the scale.

\section{Results}

The number and percentage distributions of all independent socio-demographic variables of the participant group were determined and given in Table 1.

Table 1. The number and percentage distributions of the participants for socio-demographic variables

\begin{tabular}{|c|c|c|c|}
\hline Socio-demographic Variables & Groups & $\mathbf{n}$ & $\%$ \\
\hline \multirow{4}{*}{ Age Groups } & 20 and below & 25 & 7.5 \\
\hline & Between 21 and 30 & 215 & 64.8 \\
\hline & 31 and over & 92 & 27.7 \\
\hline & Total & 332 & 100.0 \\
\hline \multirow{4}{*}{ Marital Status } & Single & 225 & 67.8 \\
\hline & Married & 100 & 30.1 \\
\hline & Widow/er-Divorced & 7 & 2.1 \\
\hline & Total & 332 & 100.0 \\
\hline \multirow{5}{*}{ Educational Status } & Primary school graduates & 7 & 2.1 \\
\hline & Secondary school graduates & 8 & 2.4 \\
\hline & High school graduates & 47 & 14.2 \\
\hline & University graduates & 270 & 81.3 \\
\hline & Total & 332 & 100.0 \\
\hline \multirow{3}{*}{ Working at a work to receive income } & Those working at a job to receive income & 189 & 56.9 \\
\hline & Those not working at a job to receive income & 143 & 43.1 \\
\hline & Total & 332 & 100.0 \\
\hline \multirow{4}{*}{ Income status } & Low & 22 & 6.6 \\
\hline & Medium & 186 & 56.0 \\
\hline & High & 124 & 37.3 \\
\hline & Total & 332 & 100.0 \\
\hline \multirow{3}{*}{ Where does the participant spend most of his/her time } & Town/County & 33 & 9.9 \\
\hline & City/Metropolitan City & 299 & 90.1 \\
\hline & Total & 332 & 100.0 \\
\hline \multirow{4}{*}{ Being satisfied of life } & Those satisfied with life & 226 & 68.1 \\
\hline & Those satisfied a little with life & 93 & 28.0 \\
\hline & Those not satisfied with life & 13 & 3.9 \\
\hline & Total & 332 & 100.0 \\
\hline
\end{tabular}

The Cronbach's Alpha internal consistency coefficient for the "A Social Skills Scale" was determined as 0.93 . The item-total score correlation values of the scale were between 0.19 and 0.55 .

As the final stage in the study, the three groups of independent socio-demographic variable subgroups and the three groups that were formed based on the frequency of sports participation (those doing sports regularly, those doing sports occasionally, and those who never do sports) were compared using the two-way analysis of variance. According to the results, there was a statistically significant difference between the groups that were formed in terms of doing sporting activities $\left(\mathrm{F}_{2,326}=3.56 ; \mathrm{p}<0.05, \eta^{2}=0.021\right)$. According to the result of the LSD Multiple Comparison Test, the source of the difference stems from the ones who engage in sports regularly and the ones who engage in sports occasionally. It was observed that the social skill levels of those who did sports occasionally was higher than that of those who did sports regularly (See Figure 1). 


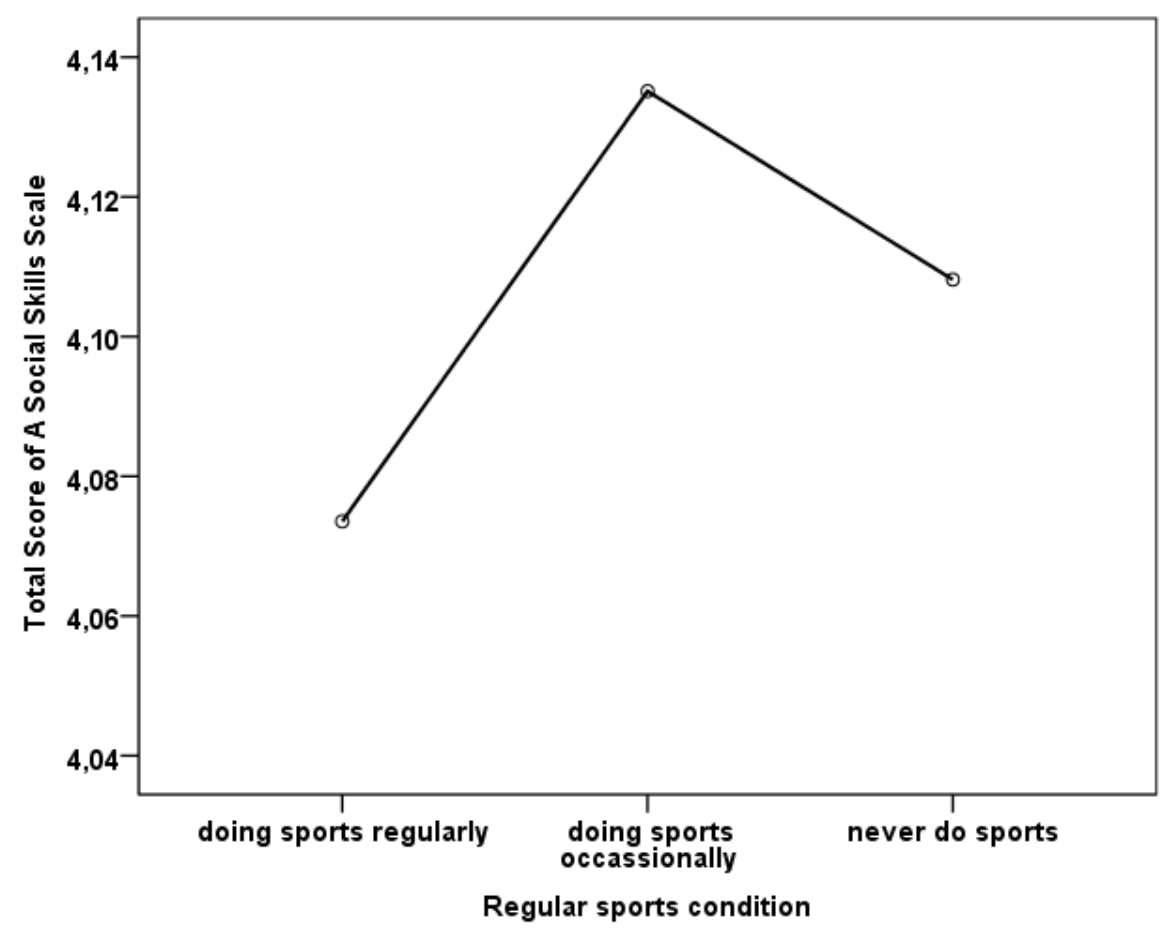

Figure 1. Group comparison based on doing sports status in terms of total score of "A Social Skills Scale" for adults Similarly, according to the results, there is a statistically significant difference between the gender groups' (female-male) total scores of the scale $\left(\mathrm{F}_{1,326}=4.36 ; \mathrm{p}<0.05, \eta^{2}=0.013\right)$ (See Figure 2) and between the two groups formed according to the "where most of the life is spent" variable (town/county and city/metropolitan city) $\left(F_{1,326}=9.53 ; p<0.01, \eta^{2}=0.028\right)$ (See Figure 3).

When the interaction results were analyzed, no interaction was detected between gender and sports participation status in terms of the total scores of the scale $\left(F_{2,326}=0.88 ; p>0.05, \eta^{2}=0.005\right)$. In other words, the social skill levels of the female and male participants do not differ according to sports participation status (See Figure 2).

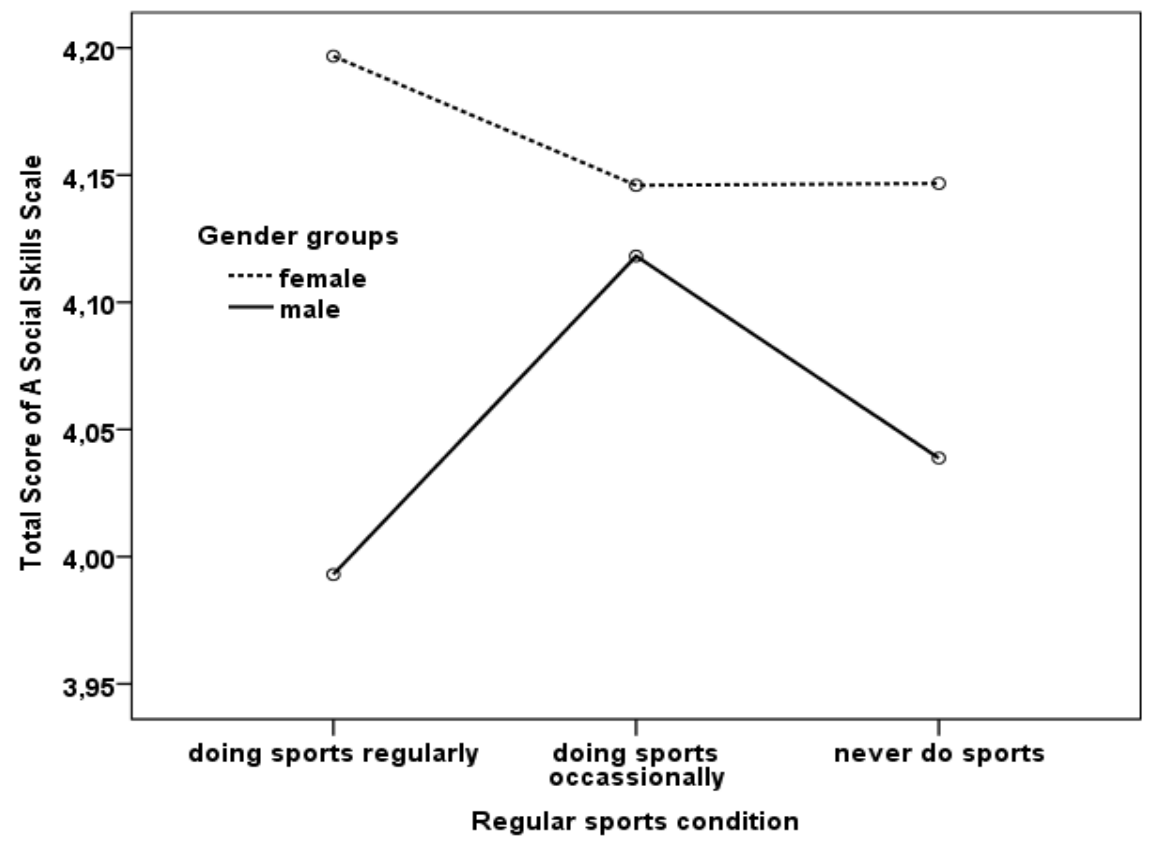

Figure 2. Comparison of groups that were formed according to doing sports and gender variables in terms of A Social Skills Scale for adults 
On the other hand, there was an interaction between the groups that were formed according to the frequency of sports participation and the groups that were formed according to where most of life was spent $\left(F_{2,326}=3.22 ; p<0.05, \eta^{2}=0.019\right)$. While there is no significant difference was observed in terms of social skill levels between those who spent most of their lives in cities/metropolitan cities engaging in sports occasionally and those who spent most of their lives in towns/cities engaging in sports occasionally as well, there was a significant difference in social skill levels of those who participate in sportive activities regularly and those who never did sports, depending on where they spent most of their lives. In this respect, the social skill levels of those who spent most of their lives in cities/metropolitan cities were higher whether they engage in sports regularly or never (See Figure 3).

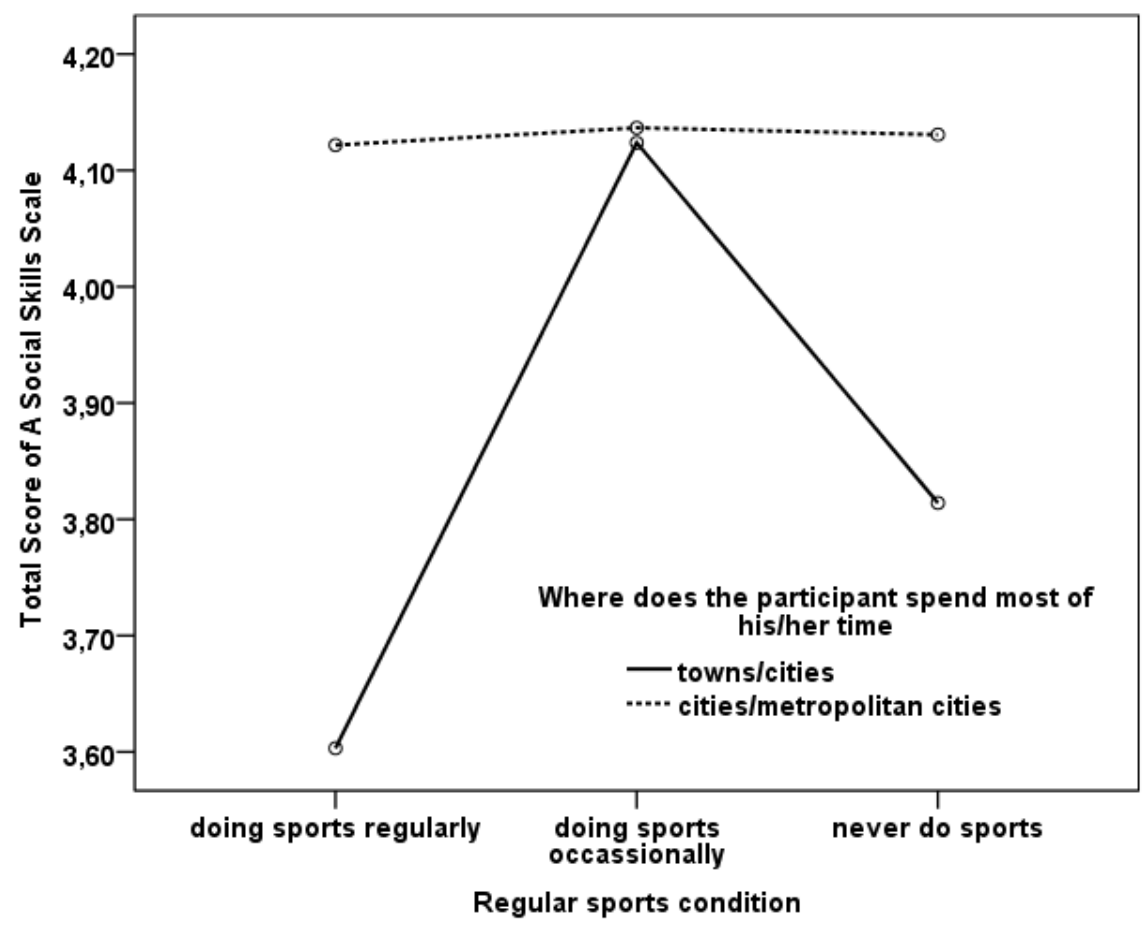

Figure 3. Comparison of groups according to where most of life is spent in terms of total scores of A Social Skills Scale for adults and doing sports variable

In the comparisons of other variables, no statistically significant differences were detected between the social skill levels of the groups that were formed based on age $\left(\mathrm{F}_{2,323}=0.55 ; \mathrm{p}>0.05, \eta^{2}=0.003\right)$, educational status $\left(\mathrm{F}_{3,322}=1.10\right.$; $\left.\mathrm{p}>0.05, \eta^{2}=0.010\right)$, marital status $\left(\mathrm{F}_{2,323}=0.97 ; \mathrm{p}>0.05, \eta^{2}=0.006\right)$, working at a job to receive income $\left(\mathrm{F}_{1,326}=1.18\right.$; $\left.\mathrm{p}>0.05, \eta^{2}=0.004\right)$, income status groups $\left(\mathrm{F}_{2,323}=1.22 ; \mathrm{p}>0.05, \eta^{2}=0.008\right)$ and satisfaction with life status $\left(\mathrm{F}_{2,324}=1.33\right.$; $\left.\mathrm{p}>0.05, \eta^{2}=0.015\right)$.

\section{Discussion}

It has been argued that doing sports has a transformative and healing effect on the physical and mental health of individuals (Guedes \& Souza, 2012) as well as on their social lives (Sekot, 2010). When sport is seen as a means of socialization, it is observed that the frequency of participation in sports activities has increased due to the motivation of people to establish relationships with other people (Iulian-Doru, Vasilica \& Maria, 2014). In this respect, it is thought that there is a relationship between doing sports and social skills. In this study, which was conducted to investigate whether there is a difference in social skill levels depending on whether or not individuals do sports, social skills were also compared in terms of socio-demographic factors.

When the level of social skills was compared in terms of the doing sports variable, according to the results obtained, the level of social skills of the people doing sports occasionally was detected to be higher than that of those who did regular sports. When considered in terms of the importance of doing sports, this result is hardly expected because of the expectation that sportsmen will be more social is considered more reasonable. However, this result seems explainable considering the fact that the participant group in this study consists of non-professional sports-doers. In addition, no information was included in the present study about what kind of sports people did. For example running alone is also considered as a sporting activity. For this reason, the results may not be surprising as there is no distinction has been made between the types of sporting activities (i.e. individual and team sports) although the participants of this study are not 
professional athletes. It is possible that these participants who engage in sports regularly have shown a lower level of social interaction under the assumption that they may have been engaging in individual sporting activities such as running alone, bicycling or swimming. In this case it is possible that occasional sports-doers have higher levels of social skills than this group because occasional sports-doers may have more social interaction in other social contexts rather than spending most of their time with sports. However, the whole interpretation should include the possibility that possible sources of error might have influenced this outcome $(n=332)$. A stronger interpretation of these results seems to be possible with a similar study in which the number of persons is greater and the types of sports done are also identified. Perhaps it is necessary to examine which of the different types of sports cause/create (or not) social skill differences.

It has been reported in the related studies that there are differences in gender groups in terms of the reasons for doing sport, the frequency of participating in sportive activities (Oliveira-Brochado et al., 2017), and the level of sport and socialization (Filiz, 2010). There are also studies showing that participation in sportive activities is age-related (Downward, Lera-Lopez \& Rasciute, 2011). In this study, there was a difference between the gender groups in terms of social skill levels. However, there was no significant difference between the social skills levels of men and women depending on sports participation. It can be shown as a reason for why there were no significant differences in the results since the types of sportive activities that gender and age groups participate in were not discriminated during evaluations because of the use of the concept of sport in a wider scope.

It is thought that the variable "where most of life is spent" was influential on the social skills of people (Krause, 2006). It is expected that the social skill levels of those who live in areas that allow social interaction are higher than the skill levels of those who live in areas that do not allow such interaction (Vanderbilt-Adriance \& Shaw, 2008). In addition, the residential area, i.e. the physical and social environment is considered to be one of the important factors determining the frequency of sports by individuals (Deliens, Deforche, Bourdeaudhuij \& Clarys, 2015; Giles-Corti \& Donovan, 2003; McNeill et al., 2006). The findings of the present study support the findings of other studies conducted to investigate the relationship between social skills, environmental factors and sports participation. As a result of the analyses made, it was found that there is an interaction between the sporting situation and the groups formed according to the place where they live. It has been observed that those who spent most of their lives in cities/metropolitan cities have higher levels of social skills whether they engage in sports regularly or not than those living in areas such as towns/counties which are relatively smaller and have low population levels. This difference seems to be the effect of the living area rather than the effect of participating or not participating in sports.

The social skills of the people who spend most of their lives in cities/metropolitan cities and the people who do regular sports and who do not do any sports being higher shows the contribution of the physical and social environment to the development of social skills. Cities that are large, crowded, and relatively more developed (in many aspects) offer individuals various possibilities for participating in social life. The spaces reserved for sports activities, which are one of these opportunities, provide areas for social interaction and increase the amount of interpersonal communication. For this reason, while individuals who live in metropolitan cities and participate in social life more actively by doing sports find the opportunity to develop their social skills, people living in areas where the population is lower than big cities, and where human density is low and social interaction is limited might have limited opportunities for improving social skills since social interaction in such areas is also limited. However, the fact that there are differences between those who spend most of their lives in cities/metropolitan cities in the groups who never do sports and those who spend most of their lives in towns/counties in terms of social skills, and the fact that those who spend most of their lives in cities/metropolitan areas showing higher social skills carry the result from sportive medium to urban opportunities.

The results of the study, when summarized as a whole, indicate that sporting has an effect in one way or another on the level of social skills. However, the direction and amount of this effect is not very clear. It is believed that when this study is methodically repeated, and when similar studies are conducted with larger participants in whom the types of sports done by individuals are also included, much clearer results will be obtained. This interpretation, at the same time, constitutes the missing points, limitations and the suggestions of the present study. This situation makes the present study to become a preliminary study and suggests that the actual work is needed.

\section{References}

Allender, S., Cowburn, G., \& Foster, C. (2006). Understanding participation in sport and physical activity among children and adults: a review of qualitative studies. Health Education Research, 21(6), 826-835. https://doi.org/10.1093/her/cyl1063

Bailey, R. (2005). Evaluating the relationship between physical education, sport and social inclusion. Educational Review, 57(1), 71-90. https://doi.org/10.1080/0013191042000274196 
Boekel, M., Bulut, O., Stanke, L., Zamora, J. R. P., Jang, Y., Kang, Y., \& Nickodem, K. (2016). Effects of participation in school sports on academic and social functioning. Journal of Applied Developmental Psychology, 46, 31-40. https://doi.org/10.1016/j.app.dev.201605.002

Deliens, T., Deforche, B., De Bourdeaudhuij, I., \& Clarys, P. (2015). Determinants of physical activity and sedentary behaviour in university students: a qualitative study using focus group discussions. BMC Public Health, 15(201), 1-9. https://doi.org/10.1186/s12889-015-1553-4

Downward, P., \& Riordan, J. (2007). Social interactions and the demand for sport: an economic analysis. Contemporary Economic Policy, 25(4), 518-537. https://doi.org/10.1111/j.1465-7287.2007.00071.x

Downward, P., Lera-Lopez, F., \& Rasciute, S. (2011). The Zero-Inflated ordered probit approach to modelling sports participation. Economic Modelling, 28(6), 2469-2477. https://doi.org/10.1016/j.econmod.2011.06.24

Eime, R. M., Young, J. A., Harvey, J. T., Charity, M. J., \& Payne, W. R. (2013). A systematic review of the psychological and social benefits of participation in sport for children and adolescents: informing development of a conceptual model of health through sport. International Journal of Behavioral Nutrition and Physical Activity, 10(98), 1-21. https://doi.org/10.1186/1479-5868-10-98

Ferguson, B. R., \& Shapiro, S. K. (2016). Using a naturalistic sport context to train social skills in children. Child \& Family Behavior Therapy, 38(1), 47-68. https://doi.org/10.1080/07317107.2016.1135700

Filiz, Z. (2010). Universite ogrencilerinin sosyallesmesinde spora katilimin degerlendirilmesi. Beden Egitimi ve Spor Bilimleri Dergisi, 4(3), 192-203.

Fraser-Thomas, J. L., Côté, J., \& Deakin, J. (2005). Youth sport programs: An avenue to foster positive youth development. Physical Education \& Sport Pedagogy, 10(1), 19-40. https://doi.org/10.1080/1740898042000334890

Gayman, A. M., Fraser-Thomas, J., Dionigi, R. A., Horton, S., \& Baker, J. (2017). Is sport good for older adults? A systematic review of psychosocial outcomes of older adults' sport participation. International Review of Sport and Exercise Psychology, 10(1), 164-185. https://doi.org/10.1080/1750 98X.2016.1199046

Giles-Corti, B., \& Donovan, R. J. (2003). Relative influences of individual, social environmental, and physical environmental correlates of walking. American Journal of Public Health, 93(9), 1583-1589. https://doi.org/10.2105/AJPH.93.9.1583

Gould, D., \& Carson, S. (2008). Life skills development through sport: Current status and future directions. International Review of Sport and Exercise Psychology, 1(1), 58-78. https://doi.org/10.1080/17509840701834573

Gould, D., Flett, R., \& Lauer, L. (2012). The relationship between psychosocial developmental and the sports climate experienced by underserved youth. Psychology of Sport and Exercise, 13(1), 80-87. https://doi.org/10.1016/j.psychsport.2011.07.005

Guedes, D. P., Souza, M. V., Ferreirinha, J. E., \& Silva, A. J. R. (2012). Physical activity and determinants of sedentary behavior in Brazilian adolescents from an underdeveloped region. Perceptual and Motor Skills, 114(2), 542-552. https://doi.org/10.2466/06.13.17.PMS.114.2.542-552

Hatfield, D. P., Chomitz, V. R., Chui, K. K., Sacheck, J. M., \& Economos, C. D. (2015). Demographic, physiologic, and psychosocial correlates of physical activity in structured exercise and sports among low-income, overweight children. Journal of Nutrition Education and Behavior, 47(5), 452-458. https://doi.org/10.1016/j.jneb.2015.05.008

Holt, N. L., \& Neely, K. C. (2011). Positive youth development through sport: A review. Revista Iberoamericana de Psicología del Ejercicio y el Deporte, 6(2), 299-316. ISSN:1886-8576

Hupp, S. D., \& Reitman, D. (1999). Improving sports skills and sportsmanship in children diagnosed with attention-deficit/hyperactivity disorder. Child and Family Behavior Therapy, 21(3), 35-51. https://doi.org/10.1300/J019v21n03_03

Iulian-Doru, T., Vasilica, G., \& Maria, T. (2014). The importance of group sports activities in adult lifelong education and in improving the quality of life. Procedia-Social and Behavioral Sciences, 117, 9-15. https://doi.org/10.1016/j.sbspro.2014.02.170

Jones, M. I., \& Lavallee, D. (2009). Exploring perceived life skills development and participation in sport. Qualitative Research in Sport and Exercise, 1(1), 36-50. https://doi.org/10.1080/19398440802567931

Kay, T. (2009). Developing through sport: Evidencing sport impacts on young people. Sport in Society, 12(9), 1177-1191. https://doi.org/10.1080/17430430903137837

Kenyon, G. S., \& McPherson, B. D. (1974). An approach to the study of sport socialization. International Review of Sport Sociology, 9(1), 127-139. https://doi.org/10.1177/101269027400900109 
Krause, N. (2006). Neighborhood deterioration, social skills, and social relationships in late life. The International Journal of Aging and Human Development, 62(3), 185-207. This research was supported by a grant from the National Institute on Aging (RO1 AG009221). https://doi.org/10.2190/7PVL-3YA2-A3QC-9M0B

Lee, K. U., Kim, H. R., \& Yi, E. S. (2014). The effect of push factors in the leisure sports participation of the retired elderly on re-socialization recovery resilience. Journal of Exercise Rehabilitation, 10(2), 92-99. https://doi.org/10.12965/2Fjer.140090

Light, R. L. (2010). Children's social and personal development through sport: A case study of an Australian swimming club. Journal of Sport and Social Issues, 34(4), 379-395. https://doi.org/10.1177/0193723510383848

Liu, Y. D. (2009). Sport and social inclusion: Evidence from the performance of public leisure facilities. Social Indicators Research, 90(2), 325-337. https://doi.org/10.1007/s11205-008-9261-4

McNeill, L. H., Kreuter, M. W., \& Subramanian, S. V. (2006). Social environment and physical activity: a review of concepts and evidence. Social Science and Medicine, 63(4), 1011-1022. https://doi.org/10.1016/j.socscimed.2006.03.012

Muñoz-Bullón, F., Sanchez-Bueno, M. J., \& Vos-Saz, A. (2017). The influence of sports participation on academic performance among students in higher education. Sport Management Review, 20(4), 365-378. https://doi.org/10.1016/j.smr.2016.10.006

Oliveira-Brochado, A., Brito, P. Q., \& Oliveira-Brochado, F. (baskıda). Correlates of adults' participation in sport and frequency of sport. Science and Sports. Doi: j.scispo.2017.03.005

Perron-Gélinas, A., Brendgen, M., \& Vitaro, F. (2017). Can sports mitigate the effects of depression and aggression on peer rejection? Journal of Applied Developmental Psychology, 50, 26-35. https://doi.org/10.1016/j.appdev.2017.03.006

Sage, G. H. (1979). Sport and the social sciences. The Annals of the American Academy of Political and Social Science, 445(1), 1-14. https://doi.org/10.1177/000271627944500103

Sekot, A. (2010). Physical activity as a sociological phenomenon. Sport Science Review, 19(5-6), 29-47. https://doi.org/10.2478/v10237-011-0031-x

Shachar, K., Ronen-Rosenbaum, T., Rosenbaum, M., Orkibi, H., \& Hamama, L. (2016). Reducing child aggression through sports intervention: The role of self-control skills and emotions. Children and Youth Services Review, 71, 241-249. https://doi.org/10.2478/v10237-011-0031-x

Smith, A. L. (2003). Peer relationships in physical activity contexts: A road less traveled in youth sport and exercise psychology research. Psychology of Sport and Exercise, 4(1), 25-39. https://doi.org/10.1016/S1469-0292(02)00015-8

Tatar, A., Ozdemir, H., Haslak, F. D., Atsizelti, S., Ozudogru, M. T., Cavusoglu, F., ... Saltukoglu, G. (2018). Yetiskinler icin A Sosyal Beceri Olcegi'nin gelistirilmesi ve psikometrik ozelliklerinin incelenmesi. Akademik Sosyal Arasttrmalar Dergisi, 6(68), 69-88.

Toepoel, V. (2013). Ageing, leisure, and social connectedness: how could leisure help reduce social isolation of older people? Social Indicators Research, 113(1), 355-372. https://doi.org/10.1007/s11205-012-0097-6

Trost, S. G., Owen, N., Bauman, A. E., Sallis, J. F., \& Brown, W. (2002). Correlates of adults' participation in physical activity: review and update. Medicine and Science in Sports and Exercise, 34(12), 1996-2001. https://doi.org/10.1097/00005768-200212000-00020

Vanderbilt-Adriance, E., \& Shaw, D. S. (2008). Protective factors and the development of resilience in the context of neighborhood disadvantage. Journal of Abnormal Child Psychology, 36(6), 887-901. https://doi.org/10.1007/s10802-008-9220-1

Vilhjalmsson, R., \& Thorlindsson, T. (1992). The integrative and physiological effects of sport participation: A study of adolescents. The Sociological Quarterly, 33(4), 637-647. https://doi.org/10.1111/j.1533-8525.1992.tb00148.x

\section{Copyrights}

Copyright for this article is retained by the author(s), with first publication rights granted to the journal.

This is an open-access article distributed under the terms and conditions of the Creative Commons Attribution license which permits unrestricted use, distribution, and reproduction in any medium, provided the original work is properly cited. 